\title{
Weed Plants of Oilseed Rape Agrocoenoses in Tomsk Oblast
}

\author{
S.I. Mikhailova, A.S. Babenko, S.A. Nuzhnyh, \\ S.A. Suchkova and T.P. Astafurova \\ Tomsk State University, Russia, 634050, Tomsk, Lenin av., 36 \\ DOI: http://dx.doi.org/10.13005/bbra/1900
}

(Received: 15 October 2015; accepted: 18 November 2015)

\begin{abstract}
The species composition of weed plants in the oilseed rape agrocoenoses in the south part of Western Siberia (Tomsk region) have been studied. There are more than 80 species of weed plants occupied oilseed rape fields on this territory. Euphorbia virgata, Convolvulus arvensis, Stachys palustris, Cirsium setosum and Sonchus arvensis belongs to the most common and widely distributed species of perennial weeds. In the seed lots of Brassica napus L. Metzg. cultivated in Tomsk Oblast the fruit and seeds of more than 40 weed seeds have been founded.
\end{abstract}

Key words: weed, oilseed rape, Tomsk Oblast

The biodiversity of non-conventional oil and feeding crops in Western Siberia is extended due to involving Brassica napus L. Metzg., Brassica rapa L. ssp. oleifera campestris, Sinapis alba L., and Camelina sativa Crantz. into production. The advantages of these crops are early ripeness, resistance to cold weather, stable crop yield and high quality of the seeds (Shpaar, 2007; Marcinkevichiene et al, 2010). There are some publication concerning oilseed rape protection in different countries. Occurrence and distribution of important weed species have been studied in German winter oilseed rape fields (Hanzlik, Gerowitt, 2012). Critical period of weed control in oilseed rape have been studied in the fields in Turkey and in Morocco (Maataoui et al., 2003; Hamzei et al., 2007). Effects on weed and invertebrate abundance and diversity of herbicide management in genetically modified herbicidetolerant winter-sown oilseed rape have been shown in some European countries (Bohan, 2005;

* To whom all correspondence should be addressed.
Debeljaka, 2008; Lutman et al, 2005).

Oilseed rape is in demand at the consumer market; it is efficient to cultivate from economic and environmental point of view. During three years from 2009 till 2012 oilseed rape cultivation area in Siberian Federal District expanded three-fold. It is the evidence of the fact that rape is of interest for manufacturers in the region. Moreover, there are all the necessary conditions to increase in the cultivation area and rape yield. It is reasonable to increase in the spring rape cultivation area up to 10 $\%$ within the cultivated crop areas in Western Siberia with rape yield increased up to $20 \mathrm{dt} / \mathrm{ha}$, as in leading farms in the region (Kashevarov et al., 2014).

To make production efficient it is necessary to reduce processing technology expenses. One of the elements of efficient protection of oilseed rape is to bring weeds under control (Sadokhina, Vlasenko, 2008; Vlasenko, Sadokhina. 2010; Popova, Petrova, 2013).

To develop effective measures to protect oilseed rape from weeds it is necessary to find out their species composition and to provide monitoring. 
In the last years the planting area of Brassica napus L. Metzg. has been extended in Tomsk Oblast. The breeds of Russian selection adapted to the strongly continental climate conditions are grown. Brassica napus L. Metzg. is grown to get green crop and seeds to produce oil.

Getting organic products means abandoning protective chemicals. Because of this the monitoring of phytosanitary state of crops becomes extremely important.

The paper aims to analyse the species composition of weed plants in oilseed rape planting areas in Tomsk Oblast.

\section{MATERIALANDMETHODS}

In 2003-2014 the phyto-sanitary state of Brassica napus L. Metzg. agrocoenoses in Tomsk Oblast was studied. The species composition of weed plants in oilseed rape planting areas was examined. The basic method we used was reconnaissance.

An additional studying method we used was the gerbological analysis of seed lots of green crops grown in Tomsk Oblast. We studied about 50 lots of oilseed rape seeds meant to produce oil and to be planted. From each lot we took a sample with a weight of 1-2 kg and collected the seeds of weed plants. We identified weed plants' species taking into account the basic morphological features of fruit, seeds and decorticated seeds (Maysuryan, Atabekova, 1978; Brouver, Shtelin, 2010; Lucometz et al, 2012).

\section{RESULTAND DISCUSSION}

\section{Weed plants on oilseed rape fields}

We revealed the species composition of weed plants characteristic of oilseed rape planting areas in Tomsk Oblast. There were more than 80 species of weed plants belonging to 26 families (Table 1.).

Among the most common and widely distributed species of perennial weeds there are Euphorbia virgata, Convolvulus arvensis, Stachys palustris, Cirsium setosum and Sonchus arvensis. Some species (Avena fatua, Echinochloa crusgalli, Panicum miliaceum ssp. ruderale, Setaria viridis, Fallopia convolvulus, Persicaria lapathifolia, Chenopodium album, Amaranthus retroflexus, Brassica campestris, Thlaspi arvense, Galeopsis bifida, Galium vaillantii) belongs to the most harmful annual weeds.

\section{Weediness of the rape seeds.}

Despite a tried-and-true method of cleaning up the seeds of oil plants in the farms of Tomsk Oblast they still contain a small amount of weed plants’ seeds (Mikhaylova, 2012).

The degree of the content of impurities in oilseed rape seeds may vary from 1.6 to $8.4 \%$. Absolute purification is impossible because of the peculiarities of weed plants' seeds - changeability of their dimensions (length, width and thickness) and their corresponding to rape seeds' dimensions. The small size (a length of $3 . . .4 \mathrm{~mm}$ ) and circular shape of oilseed rape seeds make it difficult to clean them up. Apart from this, manifold clean-up of ripe seeds may result in destroying them and deterioration of their quality.

In the seed lots of the oilseed rape grown in Tomsk Oblast we collected and identified the fruit and seeds of more than 40 weed plant species. The high occurrence is characteristic of such species as Setaria viridis, Galeopsis bifida, Galium vaillantii, Echinochloa crusgalli, Setaria viridis, Persicaria lapathifolia, Thlaspi arvense, Chenopodium album, Cirsium setosum (Table 2). Most species are the weed plants widely spread in Tomsk Oblast. It should be mentioned that nearly all the species belong to the hazardous organisms that are perilous for plant products; their mass reproduction may result in the decrease in yield and production quality (The list of extremely hazardous ..., 2010; The list of hazardous ..., 2010). Weeds description.

Brassica campestris L. - spring annual. This species is stable when cultivated continuously, it often forms a grass layer continuum; it is soil-undemanding. The species depletes the fertility of soil to a great extent consuming a lot of nutrients. The minimum temperature of seeds sprouting is $3-4^{\circ} \tilde{N}$. Seedlings grow during the whole vegetation season. Seedlings emerging in autumn do not winter usually. The excessive fertility of one plant is up to 20000 seeds. Seeds have high germination ability, they germinate from the depth less than 5-6 cm.

Chenopodium album L. - early spring weed. It has an exceptional developmental flexibility. One plant gives up to 200000 seeds, 
Table 1. The species composition of weed plants characteristic of oilseed rape planting areas in Tomsk Oblast

\begin{tabular}{|c|c|}
\hline Family, specie & Family, specie \\
\hline Equisetaceae & Geraniaceae \\
\hline Equisetum arvense L. & Erodium cicutarium (L.) L Her. \\
\hline 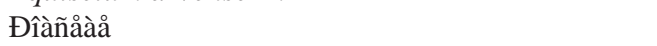 & Euphorbiaceae \\
\hline Avena fatua L. & Euphorbia helioscopia L. \\
\hline Echinochloa crusgalli (L.) Beauv. & Euphorbia virgata Waldst. et Kit., Elytrigia repens (L.) \\
\hline Nevski & Malvaceae, Malva pusilla Smith \\
\hline Panicum miliaceum ssp. ruderale (Kitag.) Tzvelev & Violaceae, Viola arvensis Murray \\
\hline Setaria pumila (Poiret) Schultes & Lythraceae, Lythrum virgatum L. \\
\hline Setaria viridis (L.) Beauv.s.str. & $\begin{array}{l}\text { Onagraceae } \\
\text { Epilobium palustre L. }\end{array}$ \\
\hline Cannabaceae & Convolvulaceae \\
\hline Cannabis sativa $\mathrm{L}$. & Convolvulus arvensis L. \\
\hline Urticaceae & Hydrophyllaceae \\
\hline Urtica dioica L. & Phacelia tanacetifolia Bentham \\
\hline Polygonaceae & Boraginaceae \\
\hline Fagopyrum tataricum (L.) & Buglossoides arvensis (L.) Johnston \\
\hline Fallopia convolvulus (L.) A. Love & Lappula squarrosa (Retz.) Dumort. \\
\hline Persicaria lapathifolia (L.) S.F. Gray & Lycopsis arvensis $\mathrm{L}$. \\
\hline Polygonum aviculare L. & Myosotis arvensis (L.) Hill, Rumex acetosella L. \\
\hline Lamiaceae & Galeopsis bifida Boenn. \\
\hline Chenopodiaceae & Galeopsis ladanum L. \\
\hline \multicolumn{2}{|l|}{ Axyris amaranthoides L. } \\
\hline Chenopodium album L. & Galeopsis speciosa Miller \\
\hline Amaranthaceae & Lamium purpureum $\mathrm{L}$. \\
\hline \multicolumn{2}{|l|}{ Amaranthus retroflexus L. } \\
\hline Amaranthus blitoides S. Wats. & Stachys annua (L.) L. \\
\hline Caryophyllaceae & Stachys palustris L. \\
\hline \multicolumn{2}{|l|}{ Cerastium holosteoides Fries } \\
\hline Elysanthe noctiflora (L.) Rupr. & Solanaceae, Hyoscyamus niger L. \\
\hline Melandrium album (Miller) Garcke & Solanum nigrum L. \\
\hline \multirow[t]{2}{*}{ Oberna behen (L.) Ikonn. } & Scrophulariaceae \\
\hline & Linaria vulgaris Miller \\
\hline Spergula arvensis L. & Veronica longifolia L. \\
\hline Stellaria graminea $\mathrm{L}$. & Plantaginaceae, Plantago media L. \\
\hline Stellaria media (L.) Villars & Rubiaceae, Galium vaillantii DC. \\
\hline Ranunculaceae & Asteraceae \\
\hline Consolida regalis S.F.Gray & Arctium tomentosum Mill. \\
\hline Fumariaceae, Fumaria officinalis L. & Artemisia vulgaris L. \\
\hline Bunias orientalis L & Brassicaceae Bidens tripartita L. \\
\hline Brassica campestris L. & Centaurea cyanus L. \\
\hline Capsella bursa-pastoris (L.) Medicus & Chamomilla recutita (L.) Rauschert \\
\hline Descurania sophia (L.) Webb, ex Prante & Cirsium setosum (Willd.) Bess. \\
\hline Erysimum cheiranthoides L. & Crepis tectorum L. \\
\hline Neslia paniculata (L.) Desv. & Gnaphalium uliginosum L. \\
\hline Raphanus raphanistrum L. & Lapsana communis L. \\
\hline Sinapis arvensis L. & Matricaria perforate Merat. \\
\hline Thlaspi arvense $\mathrm{L}$. & Ptarmica salicifolia (Bess.) Serg. \\
\hline Fabaceae & Senecio erucifolius L. \\
\hline Melilotus albus Medicus Trifolium pratense L. & Sonchus arvensis L. \\
\hline Vicia angustifolia L. & Sonchus asper (L.) Hill \\
\hline Vicia cracca L., Vicia hirsuta (L.) S.F. Gray & Taraxacum officinale Wigg. \\
\hline
\end{tabular}


each of them with hard seed coat; the maximal fecundity is 700000 seeds. Having gone through the digestive tract of animals seeds preserve their germination ability. They are polymorphous. One and the same plant can have three kinds of seeds: large, plain and brown ones germinate in the year of ripening; smaller black ones with a thick seed coat germinate during the second year after seeding; very small round black ones germinate only during the third year.

Germinating ability of seeds preserves up to 8 years. Seedlings are resistant to frost. Seeds germinate from the depth of $10 \mathrm{~cm}$. The minimum temperature of seeds' sprouting is $13^{\circ}$, the optimal one $-18-24^{\circ}$. The plant grows on all soils; the richer in nutrients is the soil, the more is the plant mass.

Cirsium setosum (Willd.) Bess. - offset weed. The breed is mainly vegetative. Vertical roots deep into the soil up to $3 \mathrm{~m}$, at a depth of $10-65 \mathrm{~cm}$ they have side horizontal roots that also deep into the soil. Under strong infestation the extension of roots amounts to $200-250 \mathrm{~m}$ in $1 \mathrm{~m}^{3}$, there are about 2 thousand buds on them. There is also seed reproduction with one plant having from 1 to 10 thousand seed pods. Seedlings come up in spring and in summer period.

Echonochloa crusgalli (L.) Beauv. annual late spring weed. On loose fertile soils it forms thick bushes. Seeds germinate at $4-6^{\circ} \tilde{N}$, the optimum temperature of germination is $26-28^{\circ} \tilde{N}$. Seedlings come up on heating soil. The excessive fertility of one plant is up to 60 thousand single seeds, which germinate from the depth less than

Table 2. Occurrence (\%) of weed seeds in the rape seed series

\begin{tabular}{lll}
\hline Species & Average & Min-Max \\
\hline Brassica campestris & $22,8 \pm 1,8$ & $12,5-50,0$ \\
Chenopodium album & $96,9 \pm 6,7$ & $87,5-100,0$ \\
Cirsium setosum & $96,4 \pm 7,5$ & $85,6-100,0$ \\
Echinochloa crusgalli & $80,4 \pm 6,4$ & $50,0-100,0$ \\
Erodium cicutarium & $72,3 \pm 3,3$ & $57,1-100,0$ \\
Galeopsis bifida & $64,7 \pm 3,2$ & $37,5-85,6$ \\
Galium vaillantii & $60,3 \pm 3,8$ & $50,0-80,5$ \\
Persicaria lapathifolia & $82,6 \pm 6,2$ & $57,1-100,0$ \\
Setaria viridis & $86,6 \pm 2,7$ & $71,4-100,0$ \\
Setaria pumila & $57,2 \pm 4,3$ & $37,5-100,0$ \\
Sonchus arvensis & $66,5 \pm 4,7$ & $50,0-87,5$ \\
Thlaspi arvense & $96,4 \pm 4,6$ & $85,6-100,0$ \\
\hline
\end{tabular}

$14 \mathrm{~cm}$ and preserve viability up to 13 years. Underride seeds are viable. For germination of single seeds the moisture and density of top soil are of paramount importance. After mowing the plant grows again; dusted with soil, parts of a plant can also grow.

Erodium cicutarium (L.) Her. - annual weed. It prefers loose sandy soil, has wintering and fall forms. The fertility of one plant is from 350 to 5600 seed pods. Fresh ripe seeds have low (5-7 $\%)$ germination ability. After wintering seeds germinate slowly from the depth less than $6 \mathrm{~cm}$. The minimum temperature of seeds sprouting is $3-$ $4^{\circ} \mathrm{C}$, optimum $-19-22^{\circ} \mathrm{C}$.

Galeopsis bifida Boenn. - annual spring weed. Seeds germinate very slowly in spring, but after seedlings coming up plants develop rapidly, from July till autumn they are in flover and bear fruit. One plant has up to 1-10 thousand nuts that hardly ever germinate in autumn.

Galium vaillantii DC. - annual spring weed. It prefers wet, fertile and rich in lime soils, has a high ecological plasticity; fertilizers enhance the growth and branching of weeds. The plant is trachyphyllous due to numerous spinules, which results in plants' lodging. The minimum temperature of seeds sprouting is $1-2^{\circ} \tilde{\mathrm{N}}$. It yields at the end of summer and in autumn. The excessive fertility of one plant is 1200 nuts. Seeds germinate from the depth less than $9 \mathrm{~cm}$. Germinating ability of fresh ripe nuts during dry years is lower than during wet years. The viability of seeds preserves up to 5 years.

Persicaria lapathifolium L. - annual early spring weed. It grows in abundance on humid soils. Seeds have a long rest and germination period. On ripening seeds shutter at once. The minimum temperature of seeds sprouting is $4-6^{\circ} \tilde{\mathrm{N}}$. The excessive fertility of one plant is 2100 nuts, which germinate from the depth less than 6-7 cm.

Setaria viridis (L.) Beauv. - annual late spring weed. The species is undemanding to soil fertility, drought-tolerant. The minimum temperature of seeds sprouting is $6-8^{\circ} \tilde{\mathrm{N}}$, optimum $20-24^{\circ} \tilde{\mathrm{N}}$. The seedlings en masse come up at the soil temperature $30-35^{\circ} \tilde{N}$. The excessive fertility of one plant is up to 3000 single seeds, which keep viability for more than 4 years. The seeds after the rest period that lasts about 12 months germinate and come up from the depth less than $14 \mathrm{~cm}$. 
Setaria pumila (Poir.) Schult. - annual late spring weed. The species is drought-tolerant. It grows in the fields and lay-lands, nearby roads, in villages, more often on sandy soil. One plant has 3-4 thousands of seeds. It reproduces by seeds. The seeds germinate at high temperature $\left(20-30^{\circ} \mathrm{C}\right)$. The seedlings come up from spring till late autumn. On tearing stems shoots grow fast from the remaining radical part.

Sonchus arvensis L. - offset weed. The species prefers light wet places, fertile aerate soils. It has a high competitive ability. It reproduces mainly in a vegetative way, by seeds insignificantly. Their root systems are fragile, small parts of roots (up to $3 \mathrm{~cm}$ ) can take roots and form shoots. The main root penetrates into the soil up to $4 \mathrm{~m}$, long side horizontal roots coming from it (1 $\mathrm{m}$ and longer) lie as deep as $6-12 \mathrm{~cm}$ and form a root net that gives start to new underground shoots developing from buds. The minimum temperature of seeds sprouting is $6-8^{\circ}$, optimum $-25-29^{\circ}$. The excessive fertility of one plant is 30000 seed pods that germinate from the depth less than $12 \mathrm{~cm}$. Seeds preserve viability up to 5 years. Fresh ripe seeds have a high germinate ability. Viability of seed pods is up to 5 years.

Thlaspi àrvense L. - annual spring weed, it can develop as a wintering one. The species grows in abundance on fields' edges and road sides. It is often found on wet fertile fields. One plant can have up to 50000 seeds, which keep germination ability up to 10 years. On ripening seeds germinate poorly (10-20\%), the germinating ability of wintering seeds rises up to $100 \%$. The seeds in soil germinate from the depth less than 4 $5 \mathrm{~cm}$. (Bazdyrev, 2004 www.agroatlas.ru).

A special attention should be paid to a fast dissemination with oilseed rape seeds of a hazardous weed plant, Echinochloa crusgalli, which is an invasive species in Siberia. Its seeds are spread with rape seeds in Tomsk Oblast and come from the southern areas of Western Siberia, which maintains the high polymorphism of the given species.

\section{CONCLUSION}

Thus, we showed the species composition of weed plants in the oilseed rape agrocoenoses in Tomsk Oblast. More than 80 species of weed plants belonging to 26 families were found out. The most wide-spread perennial weed plant species are Euphorbia virgata, Convolvulus arvensis, Stachys palustris, Cirsium setosum, Sonchus arvensis. The most dangerous annual weeds are Avena fatua, Echinochloa crusgalli, Panicum miliaceum ssp. ruderale, Setaria viridis, Fallopia convolvulus, Persicaria lapathifolia, Chenopodium album, Amaranthus retroflexus, Brassica campestris, Thlaspi arvense, Galeopsis bifida, Galium vaillantii.

In the seed lots of Brassica napus L. Metzg. cultivated in Tomsk Oblast we found the fruit and seeds of more than 40 weed seeds. The seeds of 12 weed species are found in oilseed rape seeds most frequently.

This research carried out in 2015 was supported by "The Tomsk State University Academic D.I. Mendeleev Fund Program” grant (8.1.79.2015).

\section{REFERENCES}

1. Bazdyrev, G. I., Crop protection from weeds. Moscow: Kolos, 2004.

2. Bohan, D. A., Boffey, C. W. H., Brooks, D. R., Clark, S. J., Dewar, A. M., Firbank, L. G., Haughton, A. J., Hawes, C., Heard, M. S., May, M. J., Osborne, J. L., Perry, J. N., Rothery, P., Roy, D. B., Scott, R. J., Squire, G. R., Woiwod, I. P., Champion, G. T., Effects on weed and invertebrate abundance and diversity of herbicide management in genetically modified herbicide-tolerant winter-sown oilseed rape. Proc. Roy. Soc., Ser. B 2005; 272: 463-474. DOI: 10.1098/rspb.2004.3049.

3. Brouver, V. Shtelin, A., Seed farming manual for agricultural, forest and decorative crops with the key for determination of main seeds. Moscow, 2010.

4. Debeljaka, M., Squireb, G., Demsar, D., Young, M., Dzeroski, S., Relations between the oilseed rape volunteer seed-bank, and soil factors, weed functional groups and geographical location in the UK. Ecological Modelling, 2008; 212: 138146. DOI: 10.1016/j.ecolmodel.2007.10.019.

5. Hamzei, J., Nasab, A. D. M., Khoie, F. R., Javanshir A., Critical Period of Weed Control in Three Winter Oilseed Rape (Brassica napus L.) Cultivars. Turkish J. Agric. For, 2007; 31: 8390.

6. Hanzlik, K., Gerowitt, B., Occurrence and distribution of important weed species in 
German winter oilseed rape fields. Journal of Plant Diseases and Protection, 2012; 119(3). 107-120.

7. Kashevarov, N. I., Nurlygayanov, R. B., Danilov, V. P., Potseluyev, Î. Ì., Karoma, À. N., Spring rape: cultivation stages and prospects of oilseeds production. Adaptive forage production,2014; 1: 22-27.

8. Lucometz, V. M., Piven, V. T., Tishkov, N. Ì., Bochkarev, N. I., Gorlov S.L., Krivishlykov, Ê. İ., Oilseed rape protection. Supplement to Plant protection and quarantine, 2012; 1 : 34.

9. Lutman, P. J. W., Berry, K., Payne, R. W., Simpson, E., Sweet, J. B., Champion, G. T., May, M. J., Wightman, P., Walker, K., Lainsbury, M., Persistence of seeds from crops of conventional and herbicide tolerant oilseed rape (Brassica napus). Proc. Roy. Soc. Lond. 2005; B272: 1909-1916. DOI: 10.1098/ rspb.2005.3166.

10. Maataoui, A, Bouhache, M, Benbella. M, Talouizte, A., Critical period of weed control in oilseed rape in two Moroccan regions. Commun Agric Appl Biol Sci., 2003; 68: 361-371.

11. Marcinkevichiene, A., Velicka, R., Kosteckas, R., Crop density and fertilization effects on weeds suppression in spring oilseed rape.
Zemdirbyste-Agriculture, 2010; 7(2): 83-88.

12. Maysuryan, N. A., Atabekova, À. I., Key of seeds and fruits of weed plants. Moscow, 1978.

13. Mikhaylova, S. I., Species composition of weeds in the seed lots. Agrarian Science. 2012; 9: 1920.

14. Popova, Ò. À., Petrova, N. I., Protection of spring rape from hazardous organisms. Electronic scientific journal «Apriori. Issue: Natural and technical sciences», 2013; 1: 1-10. www.apriori-journal.ru

15. Sadokhina, Ò. P., Vlasenko, N. G., Protection of rape (Brassica napus oleifera Metzg.) from pests and weeds in Western Siberia. Agricultural Chemistry, 2008; 1: 57-62.

16. Shpaar, D., Oilseed rape and bird rape (cultivation, harvesting, usage). Iî̂scow: DVL Agribusiness. The list of pests extremely hazardous for vegetable-based products. (2010). Plant Protection Newsletter, 2007; 4: 73. The list of pests extremely hazardous for vegetablebased products., Plant Protection Newsletter, 2010; 4: 74-75.

17. Vlasenko, N. G., Sadokhina, Ò. P., Impovement of the technology of cultivating cabbage cultures in Western Siberia. Agriculture, 2008; 4: 35-37. http://www.agroatlas.ru 